\title{
Musculoskeletal Implications Involving Repetitive Movements Due to Excessive Use of Mobile Devices
}

\author{
Igor Bronzeado Cahino Moura de Almeida, ${ }^{1}$ Diego Fernandes de Abreu, ${ }^{1}$ Amanda Cacaes Modesto Accioly, ${ }^{1}$ Ana \\ Karine Farias da Trindade Coelho Pereira, ${ }^{1}$ Amira Rose Costa Medeiros ${ }^{1}$
}

${ }^{1}$ Department of Morphology, Health Sciences Center, Universidade Federal da Paraíba (UFPB), João Pessoa, PB, Brasil.

Disclose and conflicts of interest: none to be declared by all authors

\begin{abstract}
Introduction: mobile Devices (MDs), such as smartphones, are becoming increasingly important in people's lives, and they use them for entertainment, to study or to work. Consequently, pathologies that were once associated with labor have been increasingly associated with these everyday activities, affecting a large number of people.

Materials and Methods: A descriptive study about the most common clinical findings and the main affected muscles in repetitive movements, according to a literature review.

Results: typing in MDs requires a new way of using the musculoskeletal system, and it mainly involves the thumb. Circular movements of the thumb don'taffect the muscles in the area, but the flexion-extension movements of the thumb cause muscle fatigue more quickly than the abduction-adduction ones. The most damaging postures are associated with typing on the lower right keys among right-handed people, because flexion-extension is the main movement used in this action, causing injuries especially in the abdutor pollicis longus of the thumb. Normally, these injuries are characterized by tendonitis or tenosynovitis, which, in this context, are repetitive-motion injuries (RMIs). De Quervain tenosynovitis and carpal tunnel syndrome, though also resulting from other situations, may as well be caused or worsened by the frequent use of MDs.

Conclusion: therefore, the rational use of these devices is recommended, taking pauses and stretching during use, and also suspending or reducing the use when the first symptoms appear.
\end{abstract}

Keywords: Smartphone; Clinical anatomy; Fist; Thumb; Tendinopathy.

\section{Introduction}

Since the end of the last century, electronic devices have been gaining more importance in people's lives. Most recently, with the rise of mobile devices (MDs) such as tablets and smartphones, people have been increasingly spending time using these devices, either to study, to work or just for entertainment.

Smartphones have many apps and functions, such as games, internet access, and cameras for photos and videos. ${ }^{1,2}$ These devices are produced annually in the order of millions, and a recent Brazilian study ${ }^{3}$ predicted that by the end of 2017, Brazil would have one smartphone per inhabitant.

The variety of possible uses of the MDs results in an increasing demand of the muscles involved in the process of typing on and handling these devices. Associated to that, there is a potential emergence of musculoskeletal disorders, such as tendonitis and general inflammations mainly related to the muscles and tendons involved in the motion of the fist joints (radiocarpal) and the numerous intrinsic hand joints. ${ }^{4}$

Besides that, the kind of activities performed is different from what people were used to in the past. Through time, there has been a notable reduction in the use of physical strength during everyday activities. ${ }^{5}$ On the other hand, with the advent of these complex and small MDs, these activities now require other kinds of physical effort, a refined neuromuscular work, similar to the work of a craftsmen.

Among the most common injuries related to the use of MDs are tendonitis, tenosynovitis and tendinopathy in general, which, in most cases, can be characterized as repetitive motion injuries (RMIs), a term that covers many alterations such as muscular pains (myalgia), fatigue and inflammation of the tendons and their covers, which generally result from the excessive use of the musculoskeletal system and from the lack of recovery time. ${ }^{6,7}$ Ragadali Filho et $a l^{8}$ point out that injuries caused by repetitive effort are disorders that affect the soft parts of the skeletal muscles, and their main origin is the overload created through time by everyday repetitive movements or bad posture. The overuse of the tendon or even its bad position during the movements can cause types of tendonitis, which is 
an inflammation of the tendon itself, or tenosynovitis, which is an inflammation of the tendon structure and of the tissue that covers it. Subsequently, if the inflammation persists, the picture of the disease can progress to a more fragile tendon, leading to even more pain than at the onset of the injury. ${ }^{9}$

Due to the increasing use of MDs and to the many pathologies associated with their excessive use, a more in-depth study, collecting multidisciplinary knowledge and synthesizing all of the current information is of great importance.

The objective of the present study was to evaluate the main muscles affected due to repetitive movements related to the use of MDs, and the clinical repercussion of that, with a review of the main associated pathologies.

\section{Materials and Methods}

A descriptive study about the main affected muscles and the respective clinical implications due to the excessive use of MDs. We used human anatomy books as reference, as well as the dissected left upper limb of a corpse from the laboratory of the Department of Morphology of Universidade Federal da Paraíba (UFPB). The study was conducted between March and May 2017.

In addition, we performed a literature review of the musculoskeletal implications related to the excessive use of MDs. The data was collected from the PubMed database using the keywords: smartphone, tendinopathy, fist and thumb. The connective and was used to link the keywords, and periodicals dating back to 1986were retrieved. Moreover, researches were performed in orthopedics and human anatomy books, in the Brazilian Virtual Health Library, and in general search websites to identify entities that deal with the subject of RMIs and ergonomics. Finally, a scientific literature review was performed to describe the mainly clinical manifestations associated with the excessive repetitive movements that can be related to the use of MDs.

\section{Results}

Musculoskeletal alterations associated with repetitive exertion are known as repetitive strain injuries (RSIs), and in the cases in which these lesions result from the individual's work, they can be called work-related musculoskeletal disorders (WRMDs), and they are, by definition, occupational illnesses.?

Tendinitis, bursitis and tenosynovitis are common in the lives of typists, a profession that was very common until the early 1990s. Between 1986 and 1987, in the city of São Paulo, Brazil, more than $88 \%$ of the cases of work accidents reported involving tenosynovitis were of typists, showing the propensity of these workers to develop RSIs. ${ }^{10-12}$ Operators of sewing machines are also a risk group for the development of RSIs, mainly tendinitis in the rotator cuff. ${ }^{13}$ A 1993 Brazilian report $^{14}$ stated that, along with deafness, RSIs were the work illnesses most notified to the Brazilian Social Security System, , and they affected workers in factory assembly lines, cashiers, packagers, registrars, among other professional categories.

Over time, with advances in technology, an increasing part of the population began to use MDs, mainly smartphones. As a consequence, pathologies that were once restricted to the work space are now related with recreational and entertainment activities, and they affect a much larger number of people.

In the 1990s, American doctors were already concernedwith tendinophaties related with the excessive use of videogames, which were mainly tendinitis in the long extensor muscle of the right thumb, which is used to press a button repeatedly. ${ }^{15,16}$ On the other hand, in the 21st century, the main concern became the excessive use of cellphones, when the short message service (SMS) became one of the most important ways of communication. Over the last decade, with the advent of touch screens, there was a significant increase in the use of MDs. In 2017, according to the Global System for Mobile Communications Association (GSMA), ${ }^{17}$ a trade body that represents the interests of mobile networkoperators worldwide, 5 billion people, which corresponds to more than $2 / 3$ of theworld's population, already owned smartphones. In addition, Europe is the continent with most smartphones, ( $86 \%$ of the European population uses this kind of device).

The use of smartphones requires the activation of certain muscles in theforearm and hands; some act just to stabilize the fist, such as the extensor digitorum (ED), the flexor digitorum superficialis (FDS), the extensor carpi radialis longus (ECRL) and the extensor carpi radialis brevis (ECRB). Meanwhile, other muscles act directly in the typing process, such as the adductor pollicis (AP), the flexor pollicis brevis (FPB), the abdutor pollicis brevis (APB), the first dorsal interosseous (FDI), and the abdutor pollicis longus (APL) (Fig. 1 and Fig. 2).

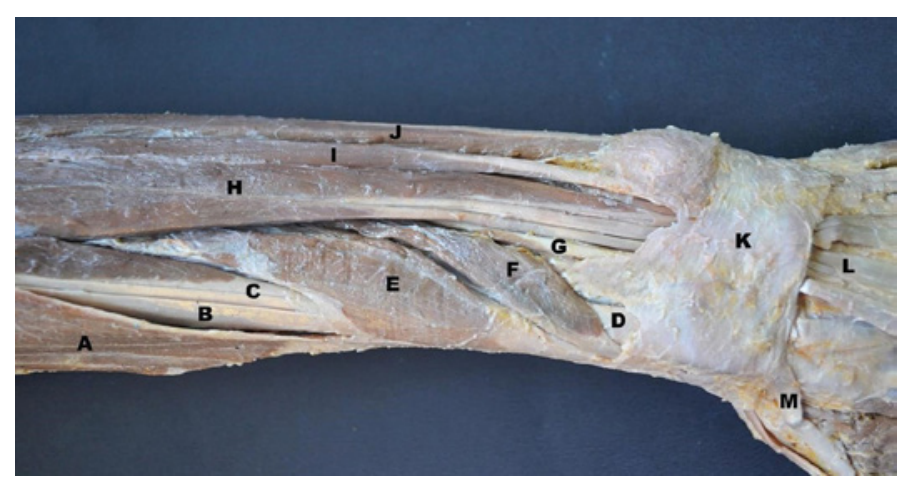

Figure 1. Dissection of the posterior forearm in a corpse from the Department of Morphology of Universidade Federal da Paraíba (UFPB), highlighting the muscles that have effect on the thumb. Source: Department of Morphology of UFPB (2017). A - Brachioradialis muscle. B Extensor carpi radialis longus muscle (ECRL). C - Extensor carpi radialis brevis muscle (ECRB). D - ECRL and ECRB muscle tendons. E - Abdutor pollicis longus muscle. $\mathrm{F}$ - Extensor pollicis brevis muscle. G - Tendon of the extensor pollicis longus muscle. $\mathrm{H}$ - Extensor digitorum muscle. I - Extensor digiti minimi muscle. $\mathrm{J}$ - Extensor carpi ulnaris muscle. $\mathrm{K}$ - Extensor retinaculum. $\mathrm{L}$ - Tendons of the extensor digitorum muscle. $M$ - Tendon of extensor pollicis longus muscle. 


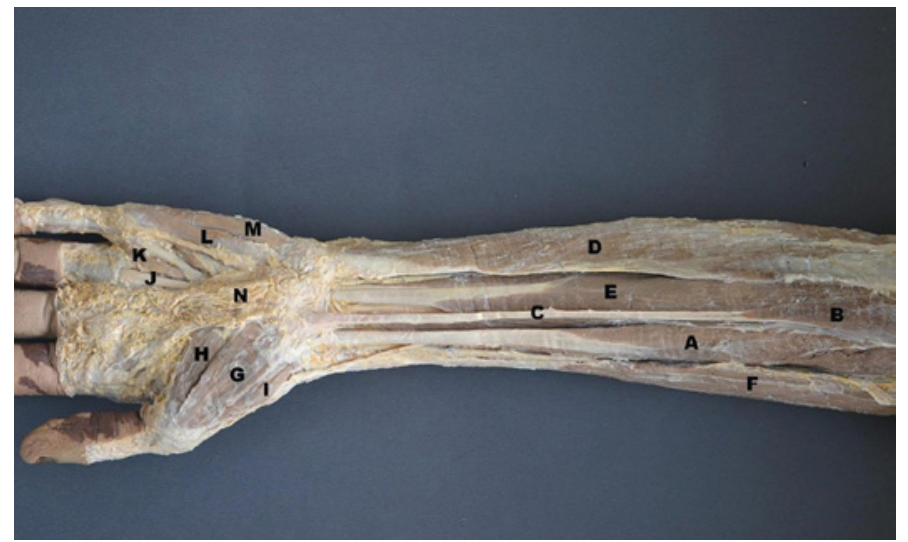

Fiure .2 Dissection of the posterior forearm in a corpse from the Departa-ment of Morphology of UFPB, highlighting the intrinsic muscles of the hand. Source: Department of Morphology of UFPB (2017). A - Flexor carpi radialis muscle. B Palmaris longus muscle. C - Tendon of the palmaris longus muscle. D - Flexor carpi ulnaris muscle. $\mathrm{E}$ - Flexor digitorum superficialis muscle. $\mathrm{F}$ - Brachioradialis muscle. G - Abdutor pollicis brevis muscle $\mathrm{H}$-Flexor pollicis brevis muscle. I Opponens pollicis muscle. J - Flexor tendon of the IV. K - Lumbrical muscle IV. $\mathrm{L}$ - Flexor digiti minimi muscle. $\mathrm{M}$ - Abdutor digiti minimi muscle. $\mathrm{N}$ - Palmar aponeurosis (partial).

Most of these forearm and wrist muscles have common features. The distal part of the forearm, in particular, requires a minimum volume to guarantee maximum functionality. Thus, most muscles in this area have their surface next to each other, and project their long tendons toward the fist and hand. Furthermore, there are the retinacula to prevent a phenome-non called "bow string", which occurs in the tendons of the forearm during the extension and flexion of the radiocarpal joints. The retinacula of the extensors and of the flexors are fibrous tissue strips that involve all of the muscular tendons of the area. Under these retinacula, the tendons run wrapped in synovial tendinous sheaths that reduce friction between them and the adjacent tissues. ${ }^{18}$

Functionally, these muscles can be grouped into an anterior compartment and a posterior compartment. The posterior compartment has the muscles related to the extension of the fist and fingers, as well as the supinator muscle, which is related to the supination movement. Most muscles in this compartment have the lateral epicondyle and the supraepi condylar crest as a common origin.19 That way, the proximal part of the extensor-supinator compartment is directed laterally. All muscles in this compartment are innervated by the radial nerve or by one of its branches (Fig. 1). Complemen-tarily, the anterior compartment contains the muscles related to the flexion of the carpus and fingers and the muscles related to the pronation movements. Most muscles in the anterior compartment have the medial epicondyle and the supraepi-condylar medial ridge of the humerus as a common origin (Fig. 2). This compartment is mostly innervated by the median nerve, and it presents some exceptions of muscles innervated by the ulnar nerve. ${ }^{20}$

Through certain activities, such as touching big and small buttons, and making clockwise and counterclockwise circular moves, and adduction- abduction and flexion-extension, varying the execution speed, it is possible to ratify the functionality of these muscles, aside from understanding the possible lesions caused by the continuous and repetitive use of these systems, which can be worsened because of bilateral or unilateral typing. . $^{21,22}$

In regular computer keyboards, the exertion and tension while typing is distributed to many fingers involved in the process, thus reducing the final load on the articulations and specific muscles. On the other hand, on smartphones, normally all the overload of the activity is on the articulations and muscles involved with the movements of the thumb. ${ }^{23}$

The act of typing bilaterally and/or unilaterally requires the ECRL, ECRB, ED, FDS, APL and APB muscles, but typing with one thumb requires more amplitude and repetition of the muscles, resulting in more activity of the muscles involved, when compared with the use of both thumbs. ${ }^{22}$ Regarding touching big and small keys, the level of effort required of the FDI muscle is much bigger when typing on small buttons, and a similar level of effort is required of the muscles to type on either big or small keys. In circular movements, there is no meaningful effect over the participating structures. In contrast, the APL and FDI muscles become extremely active during the flexionextension movements, while the APB muscle is more used during aduction-abduction. ${ }^{21,24}$

Thereby, typing on MDs mainly requires the use of the APL and APB muscles. The APL originates from the posterior surface of the radius, the ulna and the intraosseous membrane, and it emits its long tendon toward the lateral part of the fist, which is inserted in the base of metacarpal bone I. The APB shapes the lateral contour of the thenar eminence, and usually inserts itself in the radial sesamoid bone and in the base of the proximal phalanx of the thumb.

The circular movements involving the thumb don'taffect the muscles in the area. In contrast, the flexion-extension movement causes muscle fatigue more quickly than the adduction-abduction. Thus, the most damaging postures related with the movements of the thumb during typing on MDs are the ones associated with the keys located inferiorly and to the right (to right-handed people), because then the flexion-extension movements are repeatedly used, and they mainly harm the APL muscle (Fig. 3). Besides that, this muscle gets an extra overload because it is essential to stabilize the fist when handling MDs. ${ }^{24}$

Since the advent of MDs is fairly recent, the specificknowl-edge about the possible lesions caused by their use is still scarce. Thus, in the current literature there is a more generic vision regarding the appearance of tendinopathies and musculoskeletal disorders in general, which usually does not specify which tendons and muscles are more affected by the numerous possibilities of use of these technologies. Therefore, more than discussing the generic appearance of 
A
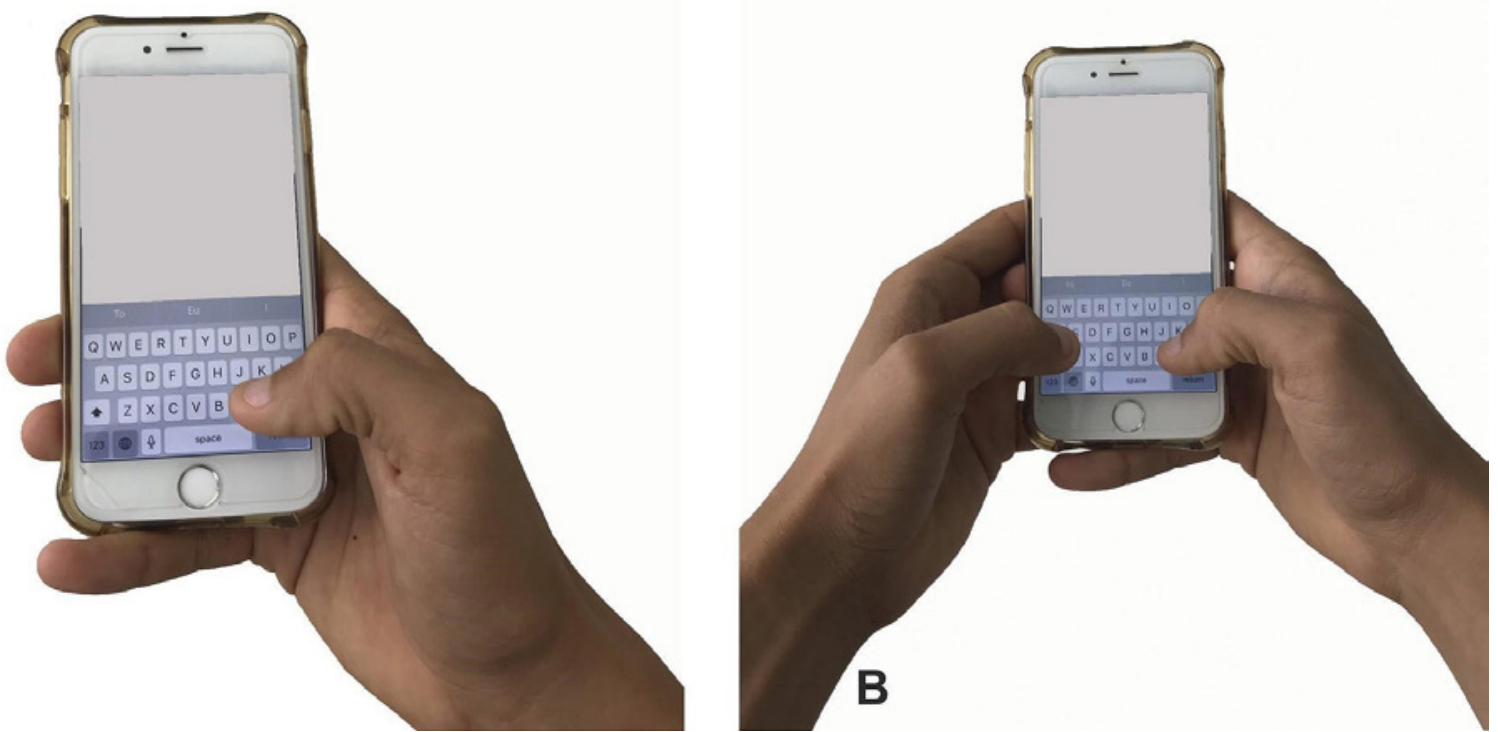

Figure 3. Different ways of handling MDs. (A) Image showing the most damaging posture, which involves unilateral handling with the keys located at the bottom right corner (to right-handed people). (B) Image showing bilateral handling with the thumbs. Source: Department of Morphology of UFPB (2017).

musculoskeletal disorders because of the excessive use of MDs, it is important to emphasize that there are well-described pathologies in the literature that are not only related to typing on these devices, but that can arise or can be worsened because of their use. Among these pathologies, De Quervain tenosynovitis and carpal tunnel syndrome (CPS) stand out.

Regarding the pathologies that have already been described in the literature, we made a review using recent periodicals and renowned books on orthopedics and traumatology. In each case, the pathophysiology, the symptomatology and the most recommended treatment are explained.

\section{De Quervain Tenosynovitis}

De Quervain tenosynovitis, which is also called "gamer's thumb" due to the repetitive movements of the thumb performed by videogames players, is a disease caused by the thickening of the retinacula of the extensors, and it involves, among other tendons, those of the long abductor and short extensor muscles of the thumb. This thickening tends to compress these tendons, which could cause the "shot" phenomenon, in which the movement of the thumb can feel blocked. ${ }^{25,26}$ Besides that, the muscles involved can become irritated, causing pain and swelling in the radial side of the fist, which results in a struggle to flex the thumb, like when suppressing movements. ${ }^{27}$ The swelling and pain in the radial side of the fist can also be symptoms of other diseases, such as intersection syndrome, carpometacarpal osteoarthritis of the thumb or Wartenberg syndrome. Thus, patient history, the physical exam, the Finkelstein and Eichoff tests must be performed in order to make a precise diagnosis. ${ }^{25}$ These tests assess the APL and EPB muscles. The Finkelstein test consists of an ulnar deviation of the carpus with the thumb stabilized, and the Eichoff test consists of an ulnar deviation while the thumb is pressed in flexion (Fig. 4). 28

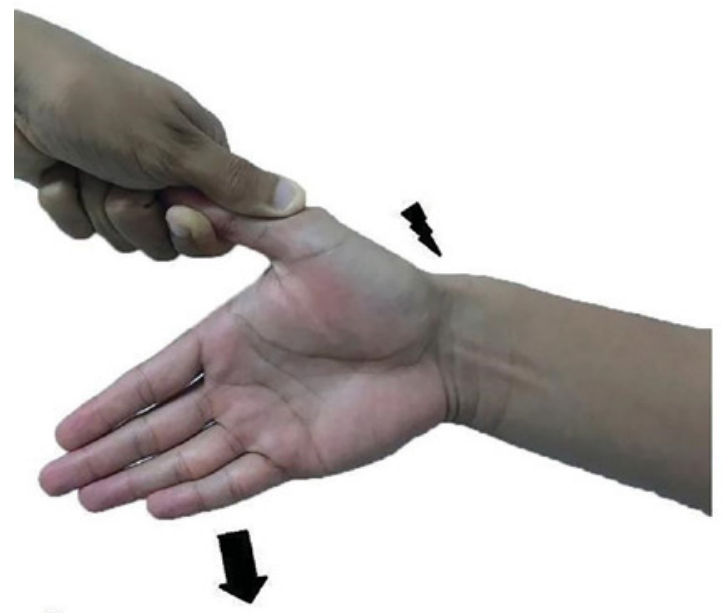

A

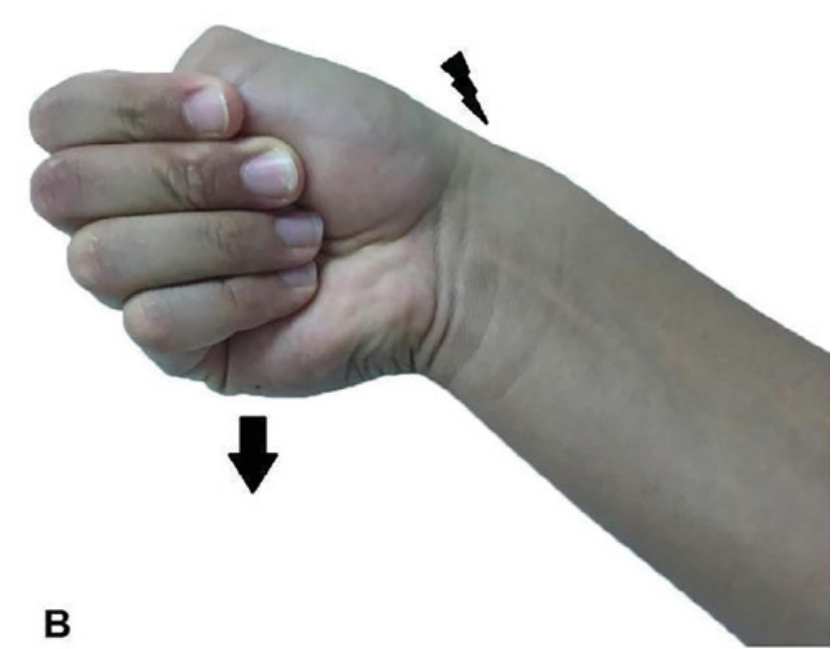

B

Figure 4. Tests to diagnose Quervain tenosynovitis. (A) Finkelstein test. (B) Eichoff test. Source: Department of Morphology of UFPB (2017). 
The mechanism that causes the disease is still unknown, but it is associated with the continuous and repetitive use of the APL and EPB muscles, which takes place while perform-ing tasks like lifting a child, holding a golf club or even typing on an MD, and these muscles are involved in the flexion-extension muscles of the thumb.

The treatment for De Quervain tenosynovitis is initially performed with a corticosteroid injection and anti-inflam-matory agents. In some cases, a thumb immobilizer must be used to reduce the pain. In addition, iontophoresis - a therapy that uses electric currents to increase the transder-mal absorption of some drugs - can be used to reduce the oral use of anti-inflammatory agents. ${ }^{25,29}$ In combination with the medicines, the patient must undergo occupational ther-apy and physiotherapy, with the aid of ultrasound exams and massage on the area. If the inflammation does not reduce with these measures, the patient must undergo surgery. ${ }^{25}$

\section{Carpal Tunnel Syndrome}

Carpal tunnel syndrome is a neuropathy that is characterized by the compression and/or traction of the median nerve at the fist. ${ }^{30,31}$ The carpal tunnel is an osteofibrous structure composed of the carpal bones and the transverse carpal ligament (the retinacula of the flexors), which involves four tendons of the FDS muscle, four tendons of the flexor digitorum profundus (FDP) muscle, one tendon of the flexor pollicis longus (FPL) muscle, and the median nerve. In most cases, CPS is considered an idiopathic disease, but it can be associated with external factors, such as obesity, pregnancy, menopause, and distal radius fracture, as well as intrinsic factors, such as tumors,

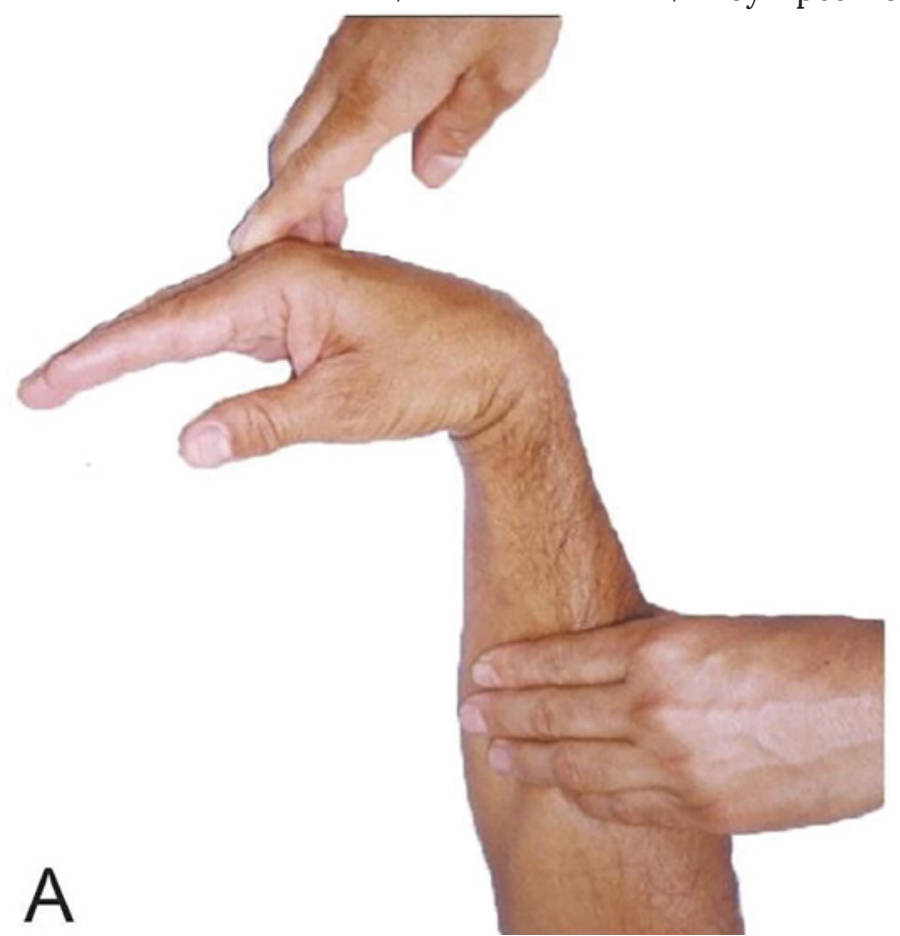

and neuropathic factors, such as diabetes, alcoholism, and vitamin deficiency. ${ }^{31}$

Repetitive movements, which are usual in activities such as typing on MDs, can cause a pressure increase in the carpal tunnel and consequently a compression of the median nerve, which results in injuries at the levels of the myelin sheath and of the axon of the nerve, aside from changes in the surrounding conjunctive tissue and in the intraneural blood microcirculation. Thus, CTS can be classified in three stages: precocious, intermediary and advanced. At the precocious stage, the swelling and numbness in the hands occur during the night, and, depending on the compression level, they can affect the intraneural microcirculation, being minimized if the fist and fingers are repositioned. At the intermediary stage, the symptoms occur during the day and night, the microcirculation is permanently affected, and lesions in the myelin sheath occur. And at the advanced stage, sensitivity and motor deficit, perceivable by the weakness and atrophy of the APB muscles and the opponens pollicis, occurs. Aside from certain tests that can be performed by the examiner, such as the Phalen and Tinel-Hofmann tests, electromyogra-phy, in which the speed of the nerve impulse is verified, is the examination that is the golden standard to confirms the precise diagnosis of CTS. ${ }^{30-32}$

The Phalen and the Tinel-Hofmann tests are exemplified below. The Phalen test consists of the maximum flexion of the fist during one minute, causing the symptoms of the syndrome. The TinelHofmann test consists of making a percussion of the median nerve at the carpus, which can also cause the symptoms of the syndrome (Fig. 5). ${ }^{33}$

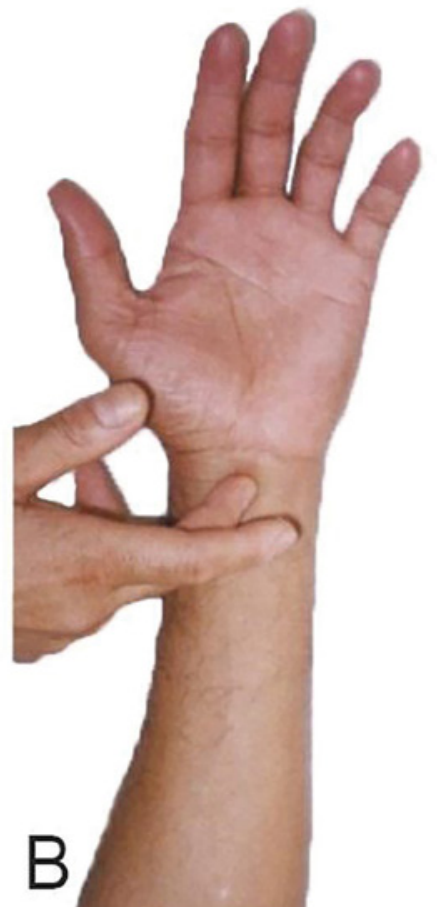

Figure 5. Tests to diagnose carpal tunnel syndrome. (A) Phalen test. (B) Tinel-Hofmann test. Source: RUARO, 2004.33 
The treatment for CPS can be conventional or surgical. The conventional treatment is based on the use of orthosis and medicines, in addition to motor physical therapy. Laser therapy represents an effective and non-invasive therapeutic modality for the severe cases, and in cases in which pain is the main symptom. In an average 6 to 21 sessions, an improvement in the patients with somatosensory neuropathy is observed. Currently, phototherapy reduces sensorial loss and improves the physiologic function of the nerves. ${ }^{34}$ The photobiomodulation effects consist of the proliferation of macrophages, lymphocytes, endothelial cells and fibroblasts. Clinical trials show its analgesic and antiinflammatory effects. ${ }^{35}$ The surgical treatment is indicated for patients with axon loss, and it is based on the release of the transverse ligament of the carpus to reduce pressure inside the compartment where the median nerve is located. ${ }^{32}$

\section{Conclusion}

The advent of new technology requires a new way of using the musculoskeletal system to type on MDs; otherwise, RMIs may occur, such as tendonitis and tendinopathy.
Differently from typing on a keyboard, in which the effort tension is divided among all of the fingers that are perform-ing the activity, during the use of MDs, such as smartphones, the thumb is usually overburdened because it performs all of the typing, while the other fingers are only used to stabilize and handle the device.

Among the movements that the thumb performs, it is notable that rotation does not cause lesions; but abduction-adduction and flexion-extension movements cause fatigue to the users. Besides that, the flexion-extension movements, which are usually performed in order to hit the keys next to the base of the thumb, are extremely damaging, causing fatigue and possible injury, mainly to the APL muscle. Additionally, pathologies such as De Quervain tenosynovitis and CPS are not uniquely linked to the excessive use of MDs, but they can be caused or worsened because of it.

The rational use of MDs, typing with both hands, taking breaks and stretching, and always reducing or suspending the use when the first pain symptoms appear, are recommended.

\section{References}

1. Lee $M$, Hong $Y$, Lee $S$, et al. The effects of smartphone use on upper extremity muscle activity and pain threshold. J Phys Ther Sci 2015;27(06):1743-1745.

2. Ko PH, Hwang YH, Liang HW. Influence of smartphone use styles on typing performance and biomechanical exposure. Ergonomics 2016;59(06):821-828.

3. Meirelles FS. Pesquisa Anual do Uso de TI nas Empresas. São Paulo: FGV/EAESP; 2017.

4. Lee $\mathrm{S}$, Kang $\mathrm{H}$, Shin $\mathrm{G}$. Head flexion angle while using a smartphone. Ergonomics 2015;58(02):220-226.

5. Ribeiro HP. Lesões por Esforços Repetitivos (LER): uma doença emblemática. Cad Saúde Pública USP. 1997;13(02):85-93

6. Ministério da Saúde (BR). Dor relacionada ao trabalho. Lesões por esforços repetitivos (LER). Distúrbios osteomusculares relacionados ao trabalho (DORT). Brasília: Ministério da Saúde; 2012.

7. Ministério da Saúde (BR). Dor relacionada ao trabalho. Lesões por esforços repetitivos (LER). Distúrbios osteomusculares relacionados ao trabalho (DORT). Brasília: Ministério da Saúde; 2012.

8. Ragadali Filho A, Leal I, Anjos QS, Leite SA, Danelussi DP. Lesões Por Esforços Repetitivos (LER): Uma Doença Misteriosa do Trabalho. Rev Saberes 2015;3(02):76-89.

9. Britto M. Ortopedia, Traumatologia e Medicina Esportiva - RJ [internet homepage]. Tendinite, tendinopatia e tendinose [viewed July 30, 2017]. Available from: http://www.marcos- britto.com/2010/07/ tendinite-tendinopatia-e-tendinose.htm.

10. Rocha LEM, Paes EM, Sobania LC. Lesões por esforços de repetição: análise em 166 digitadores de um centro de computação de dados. Rev Bras Ortop 1986;21(04):115-119.

11. Barbosa EB, Borges FD, Dias LP, Fabris G, Frigeri F, Salmaso C. Lesões por esforços repetitivos em digitadores do centro de processamento de dados do Banestado, Londrina, Paraná, Brasil. Fisioter Pesqui 1997;4(02):83-91.

12. Rocha LE. Tenossinovite e trabalho: análise das comunicações de acidentes de trabalho (CATs) registradas no município de São Paulo. Rev Bras Saúde Ocup 1990;18(70):29-39.

13. Kaergaard A, Andersen JH. Musculoskeletal disorders of the neck and shoulders in female sewing machine operators: prevalence, incidence, and prognosis. Occup Environ Med 2000;57(08): 528-534 14. Núcleo de Referência em Doenças Ocupacionais da Previdência Social. Relatório anual. Belo Horizonte: NUSAT; 1993.

15. Brasington R. Nintendinitis. N Engl J Med 1990;322(20): 1473-1474. 16. Casanova J. “Nintendinitis.” J Hand Surg Am 1991;16(01):181.

17. GSMA [internet homepage]. Number of Mobile Subscribers Worldwide Hits 5 Billion [viewed 26 October 2017]. Available from: https://www.gsma.com/newsroom/press-release/number-mobilesubscribers-worldwide-hits-5-billion.

18. Moore KL, Dalley AF, Agur AMR. Anatomia orientada para a clínica. Rio de Janeiro: Guanabara Koogan; 2006.

19- Schunke M, Schulte E, Schumacher U. Prometheus, atlas de anatomia: anatomia geral e aparelho locomotor. Rio de Janeiro: Guanabara Koogan; 2006.

20. Gardner E, Gray DJ, O'Rahilly R, Benevento R. Anatomia: estudo regional do corpo humano. Rio de Janeiro: Guanabara Koogan; 1978. 21. Xiong J, Muraki S. An ergonomics study of thumb move-ments on smartphone touch screen. Ergonomics 2014;57(06): 943-955.

22. Xie Y, Szeto GPY, Dai J, Madeleine P. A comparison of muscle activity in using touchscreen smartphone among young people with and without chronic neck-shoulder pain. Ergonomics 2016; 59(01):61-72.

23. Gabriela Stocco, Revista espaço aberto [internet homepage]. Tecnologia com bom senso [viewed 28 August 2017]. Revista Espaço Aberto, n. 144, November 2012. Available from: http:// www.usp.br/ espacoaberto/?materia=tecnologia-com-bom- senso.

24. Xiong J, Muraki S. Thumb performance of elderly users on smartphone touchscreen. Springerplus 2016;5(01):1218.

25.Goel R, Abzug JM. de Quervain's tenosynovitis: a review of the rehabilitative options. Hand (N Y) 2015;10(01):1-5.

26. Uribe W, Buendia G, Rodriguez JMF, Vieira Filho, JGC. Tenossinovites De Quervain: uma nova proposta no tratamento cirúrgico. Rev Bras Cir Plást 2010;25(03):465-469.

27. Patel KR, Tadisina KK, Gonzalez MH. De Quervain's disease. Eplasty 2013;13:ic52.

28. Arend CF. Tenossinovite e sinovite do primeiro compartimento extensor do punho: o que o ultrassonografista precisa saber. Radiol Bras 2012;45(04):219-224. 
29. de Oliveira AS, Guaratini MI, Castro CES. Fundamentação teórica para iontoforese. Rev Bras Fisioter. 2005;9(01):1-7.

30. Chammas M, Boretto J, Burmann LM, Ramos RM, Dos Santos Neto FC, Silva JB. Carpal tunnel syndrome - Part I (anatomy, physiology, etiology and diagnosis). Rev Bras Ortop 2014;49 (05):429-436.

31. Ibrahim I, Khan WS, Goddard N, Smitham P. Carpal tunnel syndrome: a review of the recent literature. Open Orthop J 2012;6:69-76.

32. Vaz MA, Freitas Cde la R, Merlo ARC. Síndrome do túnel do carpo. Rev Bras Fisioter São Carlos 2005;9(02):117-122.
33. Ruaro AF. Ortopedia e traumatologia: temas fundamentais e a reabilitação. Umuarama: Editora do Autor; 2004.

34. Fallah A, Mirzaei A, Gutknecht N, Demneh AS. Clinical effective ness of low-level laser treatment on peripheral somatosensory neuropathy. Lasers Med Sci 2017;32(03):721-728.

35. Costa SAP, Florezi GP, Artes GE, et al. The analgesic effect of photobiomodulation therapy $(830 \mathrm{~nm})$ on the masticatory muscles: a randomized, double-blind study. Braz Oral Res 2017;31:e107.
Received: September 5, 2018

Accepted: June 10, 2019
Corresponding author

Igor Bronzeado Cahino Moura de Almeida

Email: igorcahino900@gmail.com 